\title{
THE USE OF INTERNAL AUDIT IN ECONOMIC DEVELOPMENT
}

\section{Paweł Romaniuk}

\section{University of Warmia and Mazury in Olsztyn, Poland email: romaniuk1@wp.pl}

ROMANIUK, Paweł. The Use of Internal Audit in Economic Development. International and Comparative Law Review, 2011, Vol. 11, No. 1, pp. 97-106. DOI: 10.1515/iclr-2016-0098.

\begin{abstract}
The functioning of modern public administration must necessarily be related to the audit of its activities. The Polish legal system stands out because of the following criteria, which are made in the supervisory system, namely: the legality, economy, reliability and usefulness.
\end{abstract}

Keywords: adaministracja public, public management, entrepreneur.

\section{Introduction}

Internal audit in every organ of public administration and in the private sector - can help organizations achieve their goals. It aims to give managers a reasonable assurance of achieving these goals. It does not guarantee, however, to achieve these objectives. Acting with the authority of public administration or a private company, the system of internal audit may not always be ensured the reliability of financial statements and compliance with the law, but it certainly minimizes the risk in this regard. Limitations of internal audit may result primarily from:

- making wrong decisions on the basis of audit findings,

- carelessness, distraction or fatigue of workers,

- neglect by the management audit,

- collusion of persons acting together to commit or conceal a tort.

Therefore, internal audit is therefore not a cure for all evils, but - as demonstrated by the experience of the entities in which the internal audit system has been operating - it helps to seek the designated path, avoiding any unpleasant surprises on the road.

The functioning of modern public administration must necessarily be related to the audit of its activities. The Polish legal system stands out because of the following criteria, which are made in the supervisory system, namely, the legality,

\section{(c) Palacký University Olomouc, Czech Republic, 2011. ISSN 1213-8770 (print), ISSN: 2464-6601 (online).}


economy, reliability and usefulness ${ }^{1}$. These criteria are specified in the statute. It should be emphasized here that not all government entities are controlled by taking into account all criteria. As to how the body is controlled, the legislature decides. The primary objective of the audit of public entities, to ensure their smooth operation and eliminate the errors detected. It also serves as the basis for prevention and removal of malfunctioning in the future.In 2009, the Ministry of Finance - Department of Public Finance Sector Audit introduced in the amended Act on Public Finances changes in the functioning of internal audit in the public finance sector ${ }^{2}$

It is worth noting that in 2009 announced a new version of the translation of the Internal Audit Standards, which are provided in Ordinance No 1 of the Minister of Finance, 19 February 2009 on the standards of internal audit in the public finance sector. The new version of the Standards Board has introduced many changes, both in their content and structure. These changes are substantive or editorial and consist of:

- $\quad$ announcement of the interpretation of certain attributes or Standards Action,

- formulation of the new wording of certain attributes Standards, Measures and Implementations,

- $\quad$ adding new Attribute Standards, and Implementation Actions.

\section{New legislation}

Before the auditors and the heads of the units appeared in subsequent rule changes. Adopted by the Parliament Act of 27 August 2009 on public finances, which entered into force on 1 January 2010, contains many new regulations regarding the functioning of internal audit in the public finance sector.

It is worth mentioning at this point about the changes. This act, among others:

- contains a revised definition of internal audit,

- $\quad$ extends the list of units that have conducted internal audits, and also indicate those units in which audit can be conducted,

- introduces new rules for management control and internal audit,

- $\quad$ sets new rules for the coordination of management control and internal audit,

- imposes an obligation to establish audit committees, including the rules of the committees, and specifies the qualifications of members of committees,

1 Jagielski J., Control in public administration, Publishing Solicitors, Warsaw 2006, p. 67-75.

2 Act of 27 August 2009 on public finances (Journal of Laws, Number 157, item 1240 with subsequent amendments). 
- sets deadline for preparing reports on the implementation of the audit plan for the previous year to the end of January next year,

- introduces the possibility of conducting an internal audit by the provider from outside the units and determines which individuals are concerned,

- amend the list of professional qualifications of the internal auditor conducting an audit in the public finance sector ${ }^{3}$.

In discussing the position of internal audit in policy control and supervision should be to define the concept of the audit. Internal audit is an independent and objective, which aims to support the minister in charge of department or head of the aims and objectives through a systematic assessment of the management control and operations consultancy. This assessment applies in particular to the adequacy, efficiency and effectiveness of management control in a government department or unit of local government. Internal audit is carried out, for example, the Prime Minister's Office, ministries, provincial offices, customs houses, chambers of Treasury, or the National Health Fund. Internal audit is carried out also in:

1. state budgetary units, if the amount included in the financial plan or budget unit income exceeded the amount of spending the amount of 40000 thousand gold;

2. public schools, if the amount included in the plan, material and financial income or expenses exceeded the amount of 40000 thousand gold;

3. independent public health care facilities that have not been created by local government units, if the amount included in the financial plan of revenues or expenses exceed the amount of 40000 thousand gold;

4. executive agencies, if the amount included in the financial plan of revenues and expenses exceeded the amount of 40000 thousand gold;

5. state-appropriated funds, if the amount included in the financial plan of revenues and expenses exceeded the amount of 40000 thousand gold ${ }^{4}$.

Internal audit is carried out in local government units, if included in the budget resolution the amount of local government revenue and income or the amount of expenses and expenditures exceeded the amount of 40000 thousand gold. The internal audit unit carries the internal auditor employed by the entity or provider not employed in the unit, hereinafter referred to as service provider.

3 Analysis of Chapter VI, Internal Audit and the coordination of internal audit units of public finance law of 27 August 2009 on public finances (Journal of Laws, Number 157, item 1240 with subsequent amendments).

4 Article 274, paragraph 2 of the Act of 27 August 2009 on public finances (Journal of Laws, Number 157, item 1240 with subsequent amendments). 


\section{Powers of auditors}

\section{The internal auditor employed in the community may be a person who5:}

1. is a national of a Member State of the European Union or another country whose citizens, on the basis of international agreements and Community law, shall be entitled to employment on Polish territory;

2. has full legal capacity and shall exercise full civil rights;

3. has not been punished for an intentional crime or intentional tax crime;

4. have higher education;

5. has the following qualifications for internal audit:

a. one of the certifications: Certified Internal Auditor (CIA), Certified Government Auditing Professional (CGAP), Certified Information Systems Auditor (CISA), the Association of Chartered Certified Accountants (ACCA), Certified Fraud Examiner (CFE), Certification in Control Self Assessment (CCSA ), Certified Financial Services Auditor (CFSA) or Chartered Financial Analyst (CFA), or

b. passed, in 2003-2006, passed the exam on the internal auditor before the Examination Committee appointed by the Minister of Finance, or

c. powers of an auditor, or

d. two years of internal audit, and holds a postgraduate diploma in internal auditing issued by the university, which at the date of the diploma was entitled, in accordance with special regulations, to confer a doctoral degree in economics or law.

To carry out internal audit in public administration, including its organizational units, the internal auditor employed by the office of local government units authorized, respectively, mayor, mayor, city president, board chairman of the local government unit. However, when an internal audit is necessary to proceed in a unit subordinate to or supervised by, the parent unit manager or supervisor may authorize the internal auditor employed in this unit to make them ${ }^{6}$.

The local government unit head of the unit assigned tasks related to internal audit exercise, respectively, mayor, mayor, city president, board chairman of the local government unit. Very often, however, the internal auditing function are created in private companies, in addition to a functioning internal control system, strengthen the protection of resources and deal effectively with various irregularities and errors.

5 Act of 27 August 2009 on public finances (Journal of Laws, Number 157, item 1240 with subsequent amendments).

6 Por. Konrad Knedler (red.), Mirosław Stasik, Audyt wewnętrzny w praktyce. Audytoperacyjny i finansowy, Polska Akademia Rachunkowości S.A., Łódź 2005, s. 132-152. 
Head of the unit, in the office of government, which created the post of Director General of Office - Chief executive Officer, provides the conditions necessary for an independent, impartial and effective internal audit, including organizational autonomy provides internal audit and business continuity in the internal audit unit.

The internal auditor making the audit task has certain rights. Has the right to enter any premises and inspect the unit to any documents, information and data and other materials related to the functioning of individuals, including recorded on electronic data carriers, as well as to draw up their copies, duplicates, extracts, summaries or printed in compliance with regulations the mystery of the statutorily protected ${ }^{7}$. Employees are required to provide individuals with information and explanations, as well as make and certify copies, excerpts, extracts, or the statement.

An internal audit conducted on the basis of an annual internal audit plan, hereinafter called the audit plan. Where appropriate, internal audit is carried out outside the audit plan. By the end of head of internal audit in consultation with the head of the unit prepares for the risk-based audit plan for next year. Head of internal audit, conducting a risk analysis takes into account in particular the tasks arising from the business plan and guidance minister directing a branch, the audit committee and detailed guidelines for the Ministry of Finance. By the end of January each year, manager of internal audit report with the implementation of the audit plan for the previous year. The audit plan and report on the implementation of an audit plan, is available on request, public information within the meaning of the Act of 6 September 2001 on Access to public information ${ }^{8}$. Public information does not represent other documents produced by the internal auditor in the conduct of internal audit.

For the internal audit unit of local government, including its organizational units, the internal auditor employed by the office of local government units authorized, respectively, mayor, mayor, city president, board chairman of the local government unit. Where internal audit is necessary to proceed in other units in the department, the minister may authorize a department head of internal auditor employed by the Ministry for their achievements. However, where an internal audit is necessary to proceed in a unit subordinate to or supervised by, the head of the master unit or supervisor may authorize the internal auditor employed in this facility for their achievements. However, where an internal audit is necessary to proceed in the organizational units on which the camera assistant managers of complex services, inspections and guards, the gov-

7 Ustawa z dnia 5 sierpnia 2010 r. o ochronie informacji niejawnych (Dz. U. Nr 182, poz. 1228).

8 Act of 6 September 2001 on access to public information (Journal of Laws of 2001, Number 112, item 1198 with subsequent amendments). 
ernor may authorize the internal auditor employed by the regional office for their achievements.

\section{Reference to the private sector}

Executives of private companies, using the experience of public administration bodies, in order to effectively reduce the risk of their own operations and to protect the company against losses, should undergo periodic inspection of business processes, operation systems and organizational units in the structure of the body and internal control mechanisms. That the results may actually serve to improve internal processes and improve the effectiveness of controls, testing should be performed by a professional and independent auditor.

The role of auditing in private firms, a similar public institutions, is designed to monitor and improve the system of internal control mechanisms and evaluate risk management. On the basis of risk analysis, internal audit examines and evaluates functional systems businesses, as well as business processes and efficiency and adequacy of internal controls. We constantly recommend appropriate changes. Private company can create its own internal audit function, or opt for external audit. Created in the company organizational unit of the internal audit has the ability to systematically identify risk areas, in particular during the introduction of various changes and innovations ${ }^{9}$.

Related to the audit function may not perform key employees of the company. In this way, the basic rule would be broken, saying that the persons involved in the audit should not operate or be responsible for the actions, which then controlled, since their evaluation will be devoid of the characteristics of objectivity, independence and impartiality. Thus far, this principle undermines the arguments of those managers who expect that the internal audit function can execute in parallel with other employees performing executive functions in the enterprise. Many companies may be difficult to find adequately prepared personnel to work in internal audit. This problem can be solved by outsourcing or co-sourcing of auditing tasks.

Outsourcing involves delegating to outside firms specialized support for certain business processes and internal company functions that are critical to its operations, but support core activities. Specialized outsourcing services encompass many faces of the enterprise. Within contracts are commonly in information services, organization of seminars, personal consulting, accounting, finance and corporate financial analysis, legal advice, organization and management, marketing, design, technology and manufacturing, logistics, administrative and other functions ${ }^{10}$.

9 J. Marciniak, Audit personnel function in the company, Publishing Economics, Cracow 2005, p. 45-87.

10 Knedler K. (ed.), Stasik M., Internal audit practice. Operational and financial audit, Polish 
The reasons why private companies decide to delegate certain functions and business processes to external entities:

- staff an opportunity to concentrate only on business-critical tasks companies,

- improve business management,

- to knowledge and the experience of other companies,

- the possibility of using the most advanced solutions, including IT,

- matching resources to actual needs of the entity,

- reduce infrastructure costs,

- reduction in fixed costs.

However, co-sourcing also involves commissioning a company from outside the execution of certain works, for which the company has no specialized staff or sufficient resources. The difference between outsourcing and co-sourcing is that in the first case, the company assigns the entire area or task to an external company, in the second case the company shall have only part of the job, thereby helping its staff. There is no doubt therefore that in order to conclude such an agreement is primarily to improve internal processes of corporate management, a significant reduction in operating costs and increase competitiveness of the company in the market.

Entrepreneurs who plan entering into partnership with a specialist external company, they expect to benefit from the knowledge and experience of other companies without the cost of maintaining their own specialist staff. Through an agreement with the firm receives a guarantee the company access to an extensive, highly specialized knowledge and experience, supported by practitioners. Moreover, in this way the company can reduce the fixed operating costs associated with personnel costs and, above all, systematic training of workers. Does not assume any cost of staff recruitment, in the event of termination of employment - severance pay. Using external services, bear only the costs associated with the implementation of tasks specified in the contract. Executives, assigning tasks and support functions to an outsourcer, has the opportunity to focus on business-critical enterprise tasks. Freeing executives from the part of the job of understanding the issues and using the specialized professional advice, achieves much greater efficiency in business management.

In the case of larger companies outsourcing of internal audit, despite the many advantages, it is not the best solution. This is linked with greater scope, complexity and specific activity. In addition, notice the lack of continuity audits by the same auditors. The variability of staff auditors and ignorance of the spe-

Academy of Accountancy SA, Lodz 2005, p. 102-131.

(C) Palacký University Olomouc, Czech Republic, 2011.

ISSN 1213-8770 (print), ISSN: 2464-6601 (online). 
cific activities of the auditee company private limited largely objective assessment of the actual situation, to detect signs of deteriorating financial conditions, and above all the many other threats, both inherent in the company, as well as the benefits of its environment. In any large organization, the internal auditor should look at the processes occurring in the company in a continuous manner, as to date have assessed whether the system of internal control is effective, appropriate, or falling behind in all internal and external changes, whether there is reasonable assurance that the objectives of the organization, and above all - that all procedures are followed in the institution. This goal can only serve to isolate the internal auditing function within the organization. ${ }^{11}$. So much more perfect solution for larger companies will be on the basis of internal audit co-sourcing. First of all, because it is a way to supplement their own resources, internal audit specialist staff from outside. Hired an external consultant will assist the permanent staff, who also gain from the new expertise and skills.

\section{Requests for entrepreneurs}

The role played by the internal audit function within the company visible in the public administration, is reduced to monitoring, verification and evaluation of the effectiveness of risk management. In practice, internal audit can help businesses control system, with independent opinions on the functioning and effectiveness of this control. In business management, internal audit may verify the compliance of various levels with the objectives such as business valuation, and identify the specific changes that will raise the level of effectiveness of these levels.

Many enterprising people, also from the Warmia and Mazury, who dream of starting their own business, is initially dismayed by the requirements of the organization, conduct, by any bureaucratic barriers. For small businesses, all these procedures are, however, very simplified, making it easy to start business. For larger organizations, the case is somewhat complicated. Managing a large company is associated with complex decision-making process, and planning some moves in advance is becoming a necessity. The functioning of such bodies is an efficient system of internal control is used to rapid detection of problems and correcting them. The role played by the internal audit in the company amounts to monitoring, verification and evaluation of the effectiveness of risk management. In practice, tax audit internal control system may be assisted by independent opinions on the functioning and effectiveness of this control. The management of a company internal audit may verify the due-diligence of the various levels of compliance with established goals, and identify the specific changes that will raise the level of effectiveness of these levels.

But in recent years significantly increases the advisory role of internal audit, which is characterized by a specific focus on generating value added for the organi-

11 See J. Marciniak, Audit personnel function in the company, Publishing Economics, Cracow, 2005.

(C) Palacký University Olomouc, Czech Republic, 2011.

ISSN 1213-8770 (print), ISSN: 2464-6601 (online). 
zation and management support in current management ${ }^{12}$. These changes seem to induce the belief among executives that the internal audit unit may increasingly participate in the activities of the organization. What then is the future of internal audit? Does the internal auditor is able to provide the necessary assurance (with English assurance) on the proper functioning of the processes taking place in private companies, and at the same time engage in business operations while maintaining their independence?

The answer is yes. In certain situations, and to a limited extent, in accordance with the standards of the Institute of Internal Auditors (IIA stands for), the audit can actually engage in specific work, to support selected areas of the organization. However it can not assume responsibility for the functioning of these areas, because in accordance with existing regulations and practices always remain the responsibility of the management company.

In addition, the changing organizational environment of each organization, including firms, new technologies, globalization, regulatory tightening will force the entrepreneurs to constant changes. All of these factors directly affect the formation of expectations of shareholders and directors of companies and other stakeholders to the internal audit function ${ }^{13}$. The list of areas where internal audit can assist individual operators, it is long.

Internal audit should assist the organization in achieving its objectives by bringing a systematic, disciplined approach to evaluate and improve the effectiveness of risk management, internal control and corporate governance. In particular, as part of their core responsibilities, is responsible for evaluating the adequacy, efficiency and effectiveness of internal control and risk management. Mentioned in the introduction, the changes seem to induce the accelerated development of the audit, and on many other levels. Thus activate the development of new techniques of organization management, while giving some areas of particular importance. These include inter alia the principles of corporate governance and enterprise risk management process. Let's try to focus on presenting the needs and benefits of implementing these tools and to identify the role of internal audit in the process ${ }^{14}$.

Internal auditor, with its privileged position independent of the internal observer, is an important link in corporate governance. Inform the management board, board of trustees, management and external auditors about the potential problems associated with internal control, while evaluates the effectiveness of risk

12 See Kiziukiewicz T. (ed.), Internal audit units of public finance sector, Difin Publisher, Warsaw 2009.

13 Internal audit (as defined by the International Association of Internal Auditors) - activities of independent, objective assurance (with English assurance) and advisory activities, which aims to add value and improve business operations. The internal audit activity helps an organization accomplish its objectives by bringing a systematic, disciplined approach to evaluate and improve the effectiveness of risk management, internal control and corporate governance.

14 Czerniawski R., Rapacka A., Between law and finance. Explained a supervisory board member limited liability company, Wolters Kluwer, Warszawa 2007, s. 232-265. 
ICLR, 2011, Vol. 11, No. 1.

management. In addition, the internal audit unit, through direct cooperation with the board of trustees, supports its members in carrying out disclosure obligations (in accordance with the requirements of corporate governance, the supervisory board should evaluate the risk management systems and internal controls and prepare a report on that assessment.)

Audit based on risk assessment is much more efficient and effective for the entire organization. Permits to reduce the commitment of providing much more valuable and timely information, assisting the current management processes and decision-making. 